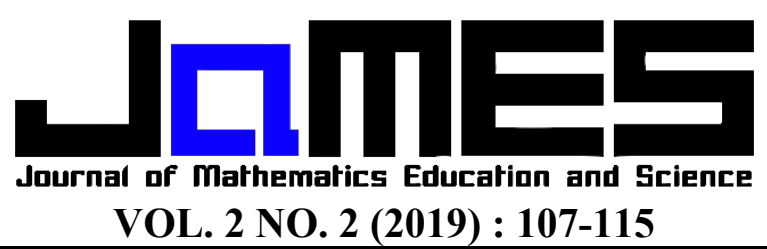

p-ISSN: 2621-1203 | https://doi.org/10.32665/james.v2i2.117

e-ISSN: 2621-1211

\title{
PENGEMBANGAN MEDIA PEMBELAJARAN BERBANTUAN SPARKOL VIDEOSCRIBE PADA MATERI TRIGONOMETRI
}

\author{
Tri Oka Akram ${ }^{1}$, Rizki Wahyu Yunian Putra ${ }^{2}$, Farida $^{3}$ \\ Universitas Islam Negeri Raden Intan Lampung, okaakramtri@gmail.com ${ }^{1}$ \\ Universitas Islam Negeri Raden Intan Lampung, rizkiwahyuyp@radenintan.ac.id ${ }^{2}$ \\ Universitas Islam Negeri Raden Intan Lampung, farida@radenintan.ac.id ${ }^{3}$ \\ Received : 28 September 2019, Revised : 19 Oktober 2019, Accepted : 20 Oktober 2019 \\ (C) Mathematics Education Unugiri 2019
}

\begin{abstract}
This research aims to produce effective and practical learning media. To achieve this goal, the authors establish the press using a research method of development with steps: (1) analysis, (2) design, (3) development, (4) implementation, (5) evaluation. The subject in this study is the participant Students at SMA N 1 Bandar Lampung with "data collection instruments used in the form of" polls provided to the material "experts, media experts," test and effectiveness tests. The results of this study resulted in a media-shaped Video learning product; Knowing the feasibility of the quality of the developed product "is very feasible with a" score of 3.66 based on material "expert assessment" and 3.66 by the media expert in a very decent category. Student response in Math Learning media with Sparkol video scribe in trigonometric material obtained score 3.33 in MIPA 4 and 3.36 class in MIPA 5 with very interesting criteria in small class test. In the massive class test obtained the score 3.43 in grade MIPA 43.41 with fascinating measures. On the effectiveness test of learning video obtained calculation results using effect size 0.54 with moderate criteria can be concluded that there is a significant increase in learning outcomes.
\end{abstract}

Keywords: Development of Mathematics Learning Media, Sparkol Videoscribe, Trigonometry

Abstrak

Penelitian ini bertujuan untuk dapat menghasilkan media pembelajaran yang efektif dan praktis. langkahlangkah yang dilakukan untuk mencapainya tujuan pembelajaran tersebut peneliti mengunggnakan metode penelitian ADDIE yaitu (1) analysis, (2) design, (3) development, (4) implementation, (5) evaluation. Adapun pada penelitian ini peserta didik SMA N 1 Bandar Lampung mejadi subjek pada penelitian, teknik pengumpulan data yang digunakan dengan menyebarkan instrument berupa angket yang diberikan pada ahli materi, ahli media, uji kemenarikan dan uji keefektifan. Video sebagai media pembelajaran yang dihasilkan dalam pengembangan yang dilakukan peneliti. Mengetahui kelayakan dari kualitas produk yang dikembangkan adalah sangat layak dengan skor 3,66 berdasarkan penilaian ahli materi dan 3,66 oleh ahli media dalam katagori sangat layak. Respon peserta didik dalam media pembelajaran matematika berbantuan sparkol videoscribe pada materi Trigonometri diperoleh skor 3,33 dikelas MIPA 4 dan 3,36 dikelas MIPA 5 dengan kriteria sangat menarik pada uji kelas kecil. pada uji kelas besar diperoleh skor 3,43 dikelas MIPA 4 3,41 dengan kriteria sangat menarik. Pada uji keefektifitasan video pembelajaran diperoleh hasil perhitungan menggunakan effect size 0,54 dengan kriteria sedang, sehingga media tersebut layak dan dapat digunakan pada saat proses pembelajaran dengan menghasilkan peningkatan keefektifan yang signifikan.

Kata kunci: Pengembangan Media Pembelajaran Matematika, Sparkol Videoscribe, Trigonometri

\section{Pendahuluan}

Media pembelajaran seperi bahan ajar adalah rencana dari kurikulum dimana semua sudah disusun menyesuaikan norma dan ketentuan yang sudah ditetapkan agar dapat menjadi panutan dalam dunia pendidikan. [4] 
Yang telah diperbaharui adalah kurikulum 2013 dahulunya adalah kurikulum tahun 2006 (KTSP). Proses pembelajaran yang lebih menekankan pada saat proses pembelajaran adalah mengamati, menanya, menalar, mencoba dan mendeskripsikan selain itu meminta peresta didik untuk mengeluarkan kebisaannya dengan adanya pembaharuan yang telah dirancang pendidik itu merupakan kegiatan peserta didik. [1]

Rencana yang diberikan dikurikulum terbaru merupakan rencana yang baik untuk dilakukan padaan proses pembelajaran namun lagi dalam hal ini tidak dapat dipungkiri ketika sudah terencana dengan baik itu hanya sebuah rencana karena sulit untuk direalisasikan karena terdapat beberapa factor yang tidak dapat mendukung dari sebagian rencana pemerintah dikurikulum terbaru ini. Salah satu permasalahan yang menonjol pada saat proses pembelajaran adalah media pembelajaran. Sehingga diperlukan adanya media pembelajaran seperti video dalam proses belajar.

Bahan ajar ataupun media yang digunakan pada saat proses belajar dan mengajar harus lebih mengikuti kemajuan teknologi yang ada pada saat ini. Alat yang dapat membantu dalam mengomunikasikan pembelajaran sering kali disebut dengan media pembelajaran. [5]

Proses pembelajaran yang tidak terlalu membuat peserta didik kurang berpartisipasi kebanyakan pada saat pembelajaran matematika dikarenakan pembelajaran lebih berfokus pada saat guru menjelaskan. [7] Sehingga pendidik dapat menyampaikan informasi juga dengan bantuan media pembelajaran. [3]

Berdasarkan permasalahan yang ada disekolah, khususnya hasil pembelajaran matematika pada materi trigonometri perlu diadakan terobosan-terobosan baru. Adanya pembaharuan yang harus digunakan pada saat proses pembelajaran adalah faktor utama yang penting untuk digunakan dalam pembelajaran adapun peneliti bertujuan untuk membentuk. media pembelajaran berupa video pembelajaran yang nantinya akan memudahkan peserta didik dalam belajar dan pembelajaran karena media seperti video ini adalah media yang dapat digunakan secara efektif, praktis dan menarik sehinggan video ini lebih membuat peserta didik belajar mandiri dalam pokok bahasan trignometri. Media pembelajaran Sparkol Videoscribe merupakan salah satu media pembelajaran yang dapat merubah pembelajaran yang efektif dan efisien.

Media pembelajaran yang terdiri dari beberapa rangkaian seperti gambar, suara, teks dan dapat menjadi animasi yaitu media pembelajaran yang dibuat dengan software Sparkol Videoscibe didalam software tersebut kita dapat membuat video yang dijadikan satu secara utuh sehingga kita dapat membuat konsep dan ide menyesuaikan materi pembelajaran yang akan kita gunakan dari video tersebut akan membuat daya tari peserta didik untuk menggunakan video yang terbuat dari software Sparkol tersebut ada banyak konten-konten yang terdapat didalam software Sparkol seperti dubbing suara yang akan menyesuaikan suara kita bagaimana menjelaskan materi yang telah kita masukan didalam software Sparkol tersebut. Selain itu pula yang lebih menciri khas kan pada software Sparkol ini adalah terdapat konten seperti kita sedang menulis dipapan tulis adanya animasi spidol dan tangan yang bergerak menulis apa yang telah kita masukan kedalam software Sparkol kira pula dapat mengatur bentuk tulisan dan berapa ukuran tulisan yang kita masukkan itu. [6] software Sparkol dapat digunakan pada saat Komputer offline sehingga software Sparkol tidak akan tergantung pada layanan internet ini merupakan pendukung pula untuk pendidik membuat media pembelajaran dari software Sparkol.

\section{Metode Penelitian}

Metode penelitian dan pengembangan (Research and development) digunakan dalam artikel ini karena penelitian ini akan menghasilkan produk tertentu. Prosedur yang digunakan dalam penelitian dan pengembangan 
ini adalah prosedur ADDIE sebagai pada Gambar 1. Tehnik pengumpulan data yang digunakan adalah penyebaran angket. Instrument yang digunakan adalah angket validasi media, validasi materi, angket respon peserta didik dan uji keefektifitasan. Tehnik analisis data yang digunakan adalah deskristif kuantitatif yang digunakan untuk mengolah data hasil validasi para ahli dan angket respon peserta didik dan tehnik deskristif kualitatif yang digunakan untuk memaparkan komentar perbaikan dan masukan oleh para validator. Adapun teknik penilaian kelayakan dan kemenarikan produk menggunakan skala likert dengan skala 1-4.

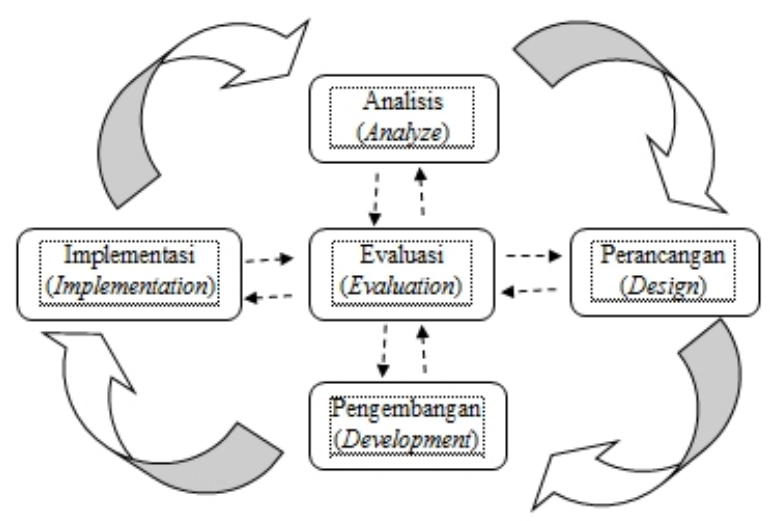

Gambar 1. Rancangan Penelitian dan Pengembangan

Tabel 1. Kriteria Validasi (Dimodifikasi)

\begin{tabular}{ccc}
\hline Skor Kualitas & $\begin{array}{c}\text { Kriteria } \\
\text { Kelayakan }\end{array}$ & Keterangan \\
\hline $3,26<\bar{x} \leq 4,00$ & $\begin{array}{c}\text { Valid/sangat } \\
\text { layak digunakan }\end{array}$ & Tidak Revisi \\
\hline \multirow{3}{*}{$2,51<\bar{x} \leq 3,26$} & $\begin{array}{c}\text { Cukup } \\
\text { Valid/layak } \\
\text { digunakan }\end{array}$ & Revisi Sebagian \\
\hline & $\begin{array}{c}\text { Kurang } \\
\text { Valid/layak } \\
\text { digunakan }\end{array}$ & $\begin{array}{c}\text { Revisi Sebagian } \\
\text { \& Pengkajian } \\
\text { Ulang Materi }\end{array}$ \\
\hline $1,76<\bar{x} \leq 2,51$ & $\begin{array}{c}\text { Tidak } \\
\text { Valid/layak } \\
\text { digunakan }\end{array}$ & Revisi Total \\
\hline
\end{tabular}

Tabel 2. Kategori Effect Size [2]

\begin{tabular}{cc}
\hline Effect Size & Kategori \\
\hline $\mathrm{d} \leq 0,2$ & Kecil \\
\hline $0,2<\mathrm{d} \leq 0,8$ & Sedang \\
\hline $\mathrm{d}>0,8$ & Tinggi \\
\hline
\end{tabular}

\section{Hasil Penelitian}

Video pembelajaran berbantuan sparkol videoscribe merupak media pembelajaran yang dikembangkan oleh peneliti. Addie adalah metode yang digunakan dalam pengembangan media pembelajaran ini. Berikut hasil penelitian dari tahap 1 sampai dengan tahap 5.

\section{Analyze (Tahap Analisis)}

Pada tahap analisis ini hasil yang diperoleh digunakan untuk bahan pertimbangan dan struktur dalam penyusunan. Pada tahapan ini dilakukan analisis karakteristik peserta didik dan analisis kebutuhan.

a. Analisis Kebutuhan

Dalam mengatasi masalah yang terjadi disekolah khususnya pada pembelajaran matematika yang digunakan guru untuk proses pembelajaran adalah media pembelajaran. Beberapa permasalahan tersebut terjadi di jenjang SMA, sehingga perlu adanya media pembelajaran yang menunjang peserta didik untuk belajar yang mandiri. Pada era sekarang media pembelajaran Video dapat menunjang pembelajaran yang dibutuhkan.

b. Analisis Karakteristik Peserta didik

Dari hasil pada saat wawancara ke guru yang mengajar pembelajaran matematika dan ke peserta didik. Adapun disimpulkan sebagai berikut:

1) Peserta didik banyak yang kurang merasa ingin tahu pada pembelajaran matematika ketika menggunakan buku saja.

2) Hasil pembelajaran peserta didik masih dibilang rendah pada pembelajaran matematika khususnya konsep pembelajaran trigonometri.

3) Semangat peserta didik sangat kurang pada saat proses pembelajran karen pendidik selalu dengan menggunakan metode ceramah.

4) Adanya pembaharuan terhadap media pembelajaran merupakan sesuatu yang dibutuhkan peserta didik pada saat proses pembelajaran.

Dari hasil analisis tersebut peneliti menyimpulkan dengan mengembangkan media pembelajaran berbantuan sparkol videoscribe 
dapat merubah proses pembelajaran yang terlalu monoton ke buku saja.

\section{Design (Tahap Perancangan)}

Setelah dilakukan analisis langkah selanjutnya adalah tahapan design. Tahapan yang dilakukan dalam tahap design produk pengembangan media pembelajaran Sparkol Videooscribe yaitu:

a. Desain dari media

Sparkol videoscribe adalah aplikasi yang digunakan untuk membuat video pembelajaran. menggunakan huruf Arial Rounded MT Bold. Penyusunan desain video yaitu dimulai dengan membuat pembukaan awal, judul materi beserta sub babnya, kompetensi inti, kompetensi dasar, materi , latihan soal, penutup. Pada kegiatan pembelajaran pada video pembelajaran terdiri dari penjelasan materi, latihan soal. Disetiap layar pada video akan diberikan audio musik dan penjelasan.

\section{b. Perancangan Instrumen}

Angket (kuesioner) disusun untuk mengevaluasi media yang telah dibuat. Penyusunan instrument dilakukan berdasarkan aspek-aspek yang disesuaikan dengan tujuan masing-masing angket. Instrumen tersebut diantaranya angket evaluasi oleh ahli media, ahli materi. Angket tersebut diberikan kepada para ahli ketika mereview media sebelum diujicobakan di lapangan. Sedangkan angket setelah uji coba diberikan kepada peserta didik berupa angket respon terhadap media.

Setelah dilakukan tahap perancangan, selanjutnya dilakukan evaluasi penyusunan dalam media ini meliputi pembukaan awal, judul materi beserta sub babnya, kompetensi inti, kompetensi dasar, materi, latihan soal, penutup. Materi pada media ini disusun berdasarkan Kompetensi Inti dan Kompetensi Dasar yang telah ditetapkan. Pembuatan media pembelajaran ini menggunakan Sparkol Video Scribe.

\section{Development (Tahap Pengembangan)}

Tahap pengemabangan, adapun beberapa tahap yang dilakukan pada tahap ini sebagai berikut.

110 a. Pembuatan video

Pada tahap pembuatan video ini, garis besar isi video dikembangkan menjadi sebuah media pembelajaran berbentuk video.

1) Pembuka Video.

Awal dari video ini adanya instrumen, ucapan salam, judul materi dan sub bab. Gambar dan background yang dipilih disesuaikan dengan warna yang menarik. Warna dan gambar yang digunakan menysuaikan. Berikut ini adalah tampilan pembuka dari video pembelajaran Trigonometri yang telah didesain.

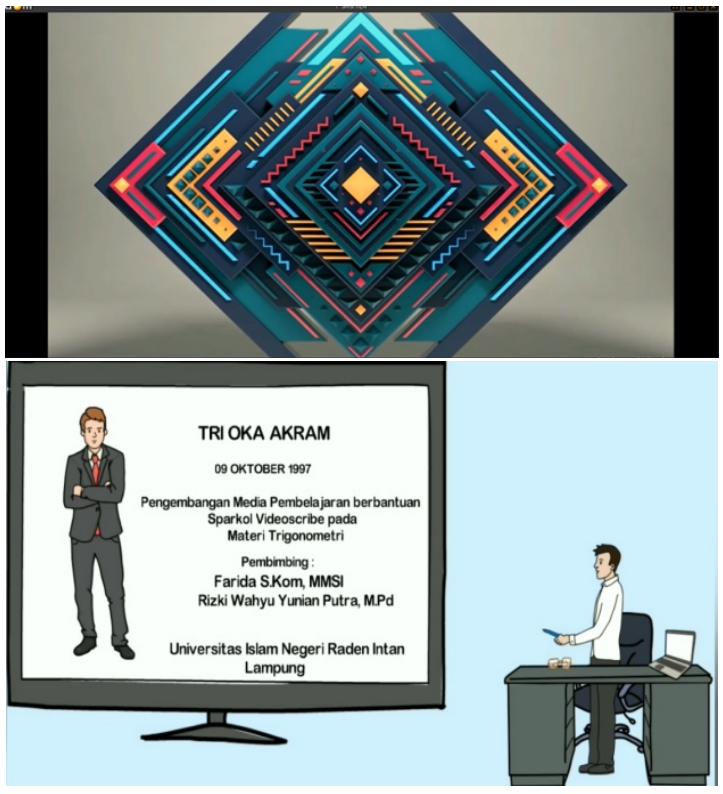

Gambar 2. Tampilan awal

2) Kegiatan Belajar

Video ini disusun dengan strutur sehingga materi juga disesuaikan dengan jelas. Adanya pembeda dari tiap materi 1 ke materi 2 dan selanjutnya. Dengan tujuan agar peserta didik dapat mengetahui diamana letak-latak per sub materinya.dari tiap sub materi tersusun juga adanya uraian materi, contoh soal dan latihan.

\section{Uraian materi}

Pada uraian materi ini adanya penjelasan materi yang tersusun. Berikut ini adalah salah satu contoh uraian materi yang terdapat dalam video. 


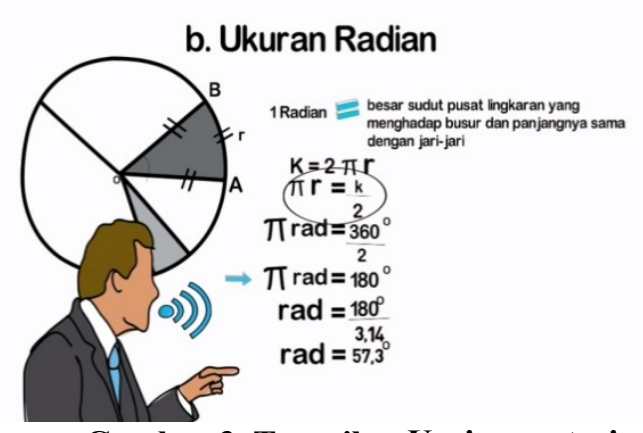

Gambar 3. Tampilan Uraian materi

\section{Contoh soal}

Contoh soal berisi contoh soal dan penyelesaian dari materi yang telah dipelajari. Berikut ini adalah salah satu contoh soal yang terdapat dalam video.

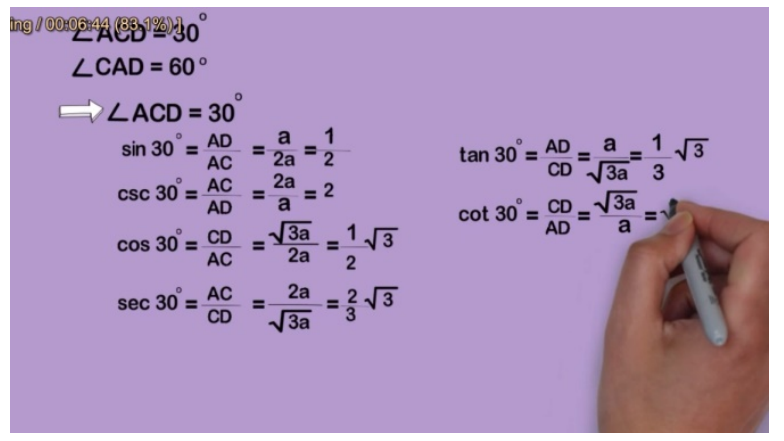

Gambar 4. Tampilan Contoh Soal

\section{Latihan}

Latihan soal selalu diselipkan pada materi-materi sub bab yang dibuat. Dengan tujuan untuk mengkaji dari pengetahuan peserta didik dari materi-materi yang sudah disajikan tersebut. juga dikaitkan dengan konsep materi yang telah dipelajari peserta didik. Berikut ini adalah salah satu contoh latihan yang terdapat dalam video.

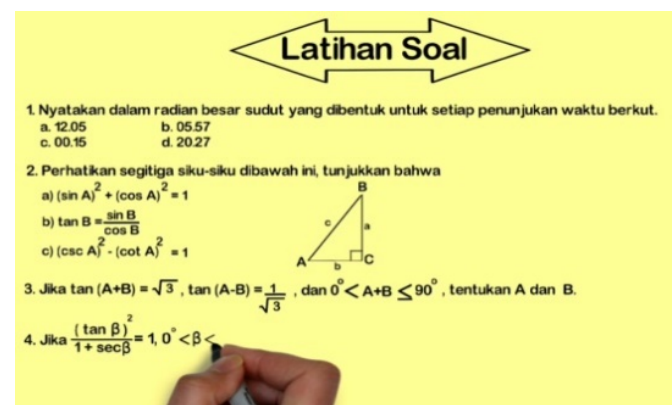

Gambar 5. Tampilan Latihan

\section{b. Validasi Produk}

Maksud dari validasi produk ini adalah agar adanya pertimbanagn atau masukan ahli media dan ahli materi agar tersusunnya media pembelajaran yang dapat digunakan secara maksimal.

Ada 3 validator untuk ahli media dan 3 validator untuk ahli materi. Adapun hasil validasi ahli sebagai berikut:

\section{1) Hasil Validasi Ahli Materi}

Validasi ahli materi bertujuan untuk menguji kelengkapan materi, kebenaran materi dan sistematika materi. Hasil data validasi materi tahap 1 terjadi peningkatan yang sangat signifikan dari tahap 1 ke tahap 2, baik pada aspek kesesuaian materi dengan $\mathrm{KI} \mathrm{KD}$, keakuratan materi, mendorong keingintahuan, teknik penyajian, penyajian pembelajaran, koherensi dan keruntutan alur pikir, kontekstual.

\section{2) Hasil Validasi Ahli Media \\ Video pembelajaran yang dibuat} berbantuan sparkol videoscribe akan divalidasi agar dapat dilihat dari penyajiannya dan sebagainya. Hasil dari validasi ahli tersebut adanya peningkatan dari mulai validasi tahap 1 hingga validasi tahap 2. baik pada aspek pewarnaan, aspek pemakaian kata dan bahasa, aspek tampilan pada layar, aspek penyajian, aspek animation dan suara.

\section{c. Revisi Pembuatan Produk}

Setelah desain produk divalidasi melalui penilaian dari ahli materi, ahli media maka peneliti melakukan revisi terhadap desain oengembangan produk berdasarkan masukan dari para ahli. Adapun saran/masukan untuk perbaikan adalah sebagai berikut:

a) Saran/Masukan Ahli Materi

Pada saat tahap validasi ahli materi, validator memberikan saran/masukan agar produk yang dihasilkan lebih baik dari sebelumnya. Saran/masukan dari validator ahli materi tersebut dapat dilihat pada tabel 4.5 berikut: 
Tabel 3. Saran Perbaikan Validasi Ahli Materi

\begin{tabular}{|c|c|}
\hline Aspek & $\begin{array}{c}\text { Saran/Masukan untuk } \\
\text { perbaikan }\end{array}$ \\
\hline $\begin{array}{l}\text { Kesesuaian materi } \\
\text { dengan KI dan KD }\end{array}$ & $\begin{array}{l}\text { - Tambahkan KI yang } \\
\text { dituju }\end{array}$ \\
\hline Keakuratan materi & $\begin{array}{l}\text { - } \begin{array}{l}\text { Berikan penjelasan yang } \\
\text { lebih detail pada awal } \\
\text { materi }\end{array} \\
\end{array}$ \\
\hline $\begin{array}{c}\text { Mendorong } \\
\text { keingintahuan }\end{array}$ & $\begin{array}{c}\text { - Tambahkan kekurangan" } \\
\text { yang ada disetiap materi }\end{array}$ \\
\hline Teknik penyajian & $\begin{array}{l}\text { - Perbaiki kejelasan dari } \\
\text { setiap sub bab disetiap } \\
\text { materi } \\
\text { - } \quad \text { Sesuaikan suara dengan } \\
\text { animasi yang berjalan }\end{array}$ \\
\hline $\begin{array}{c}\text { Penyajian } \\
\text { pembelajaran }\end{array}$ & Tidak ada revisi \\
\hline $\begin{array}{l}\text { Koherensi dan } \\
\text { keruntutan alur } \\
\text { pikir }\end{array}$ & $\begin{array}{l}\text { - Tambahkan konsep dan } \\
\text { teori-teorinya pada setiap } \\
\text { penjelasan }\end{array}$ \\
\hline Kontekstual & Tidak ada revisi \\
\hline
\end{tabular}

Berdasarkan Tabel 3 dapat dilihat bahwa perbaikan pada aspek kesesuaian materi dengan KI telah diperbaiki menurut saran dari ahli materi disajikan dalam gambar sebagai berikut:

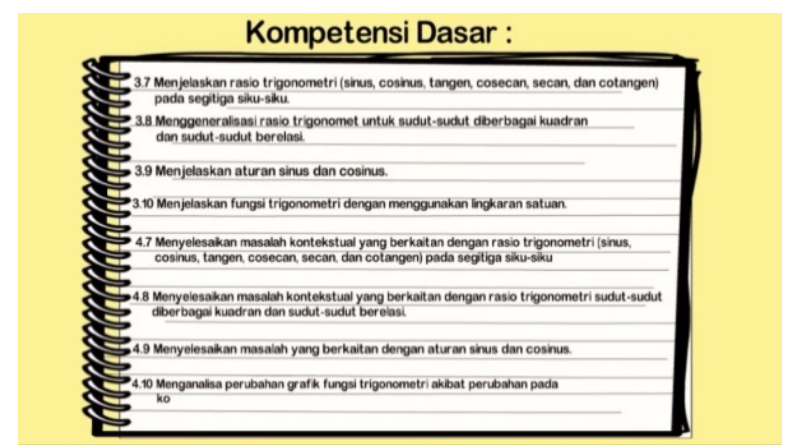

(a) Sebelum revisi

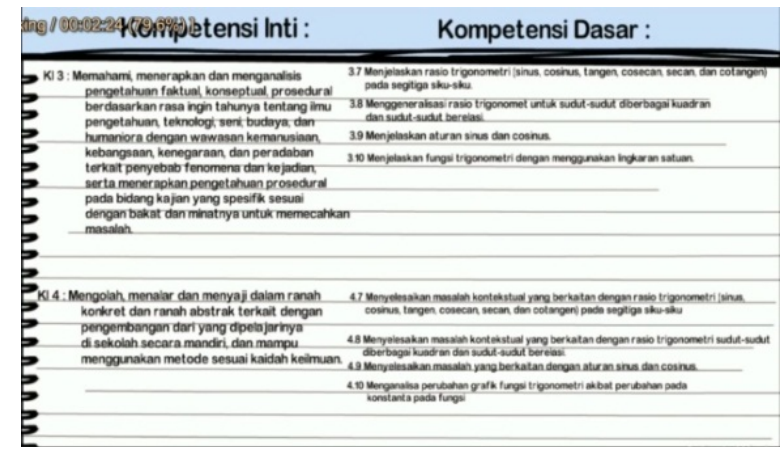

(b) Setelah revisi

Gambar 6. Tampilan perbaikan pada KI dan KD yang dituju
Hasil dari perbaikan menurut saran dari ahli materi disajikan dalam gambar sebagai berikut:

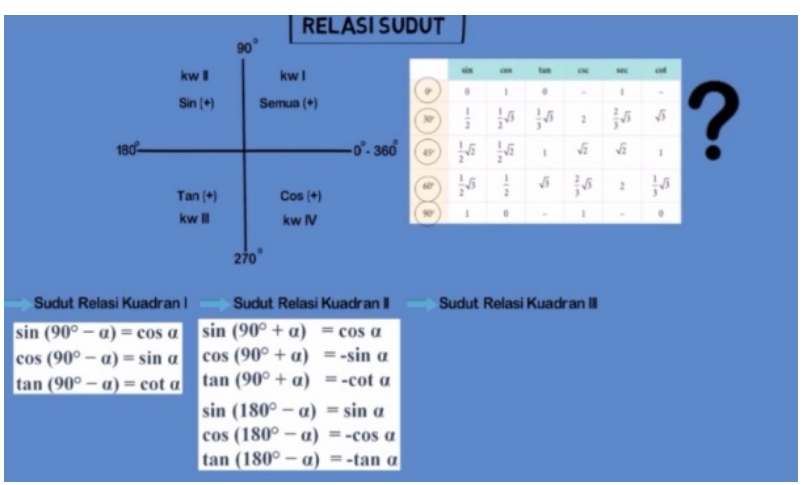

(a) Sebelum revisi

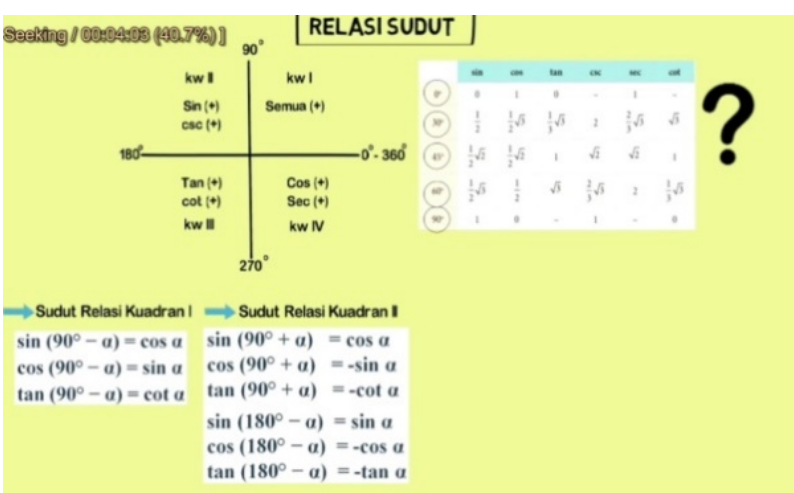

(b) Setelah revisi

Gambar 7. Perbaikan kesalahan pada materi

b) Saran/Masukan Ahli Media

Saran/masukan yang bermanfaat sebagai acuan untuk memperbaiki kualitas media dari video pembelajaran agar lebih baik diberikan oleh validator. Pada tabel berikut ini adalah saran dan masukan yang diberikan oleh validator:

\section{Tabel 4. Saran Perbaikan Validasi Ahli Media}

\begin{tabular}{|c|c|}
\hline Aspek & Saran/Masukan untuk perbaikan \\
\hline Pewarnaan & $\begin{array}{l}\text { - Warnanya diganti yang lebih bagus } \\
\text { dan selaras }\end{array}$ \\
\hline $\begin{array}{l}\text { Pemakaian } \\
\text { kata dan } \\
\text { bahasa }\end{array}$ & $\begin{array}{l}\text { - Bahasa yang digunakan harus lebih } \\
\text { baik }\end{array}$ \\
\hline Penyajian & $\begin{array}{ll}\text { - } & \text { Tambahkan pembukaan } \\
\text { - } & \text { Tambahkan persembahan } \\
\text { - } & \text { Kecilkan suara backround music } \\
\end{array}$ \\
\hline $\begin{array}{c}\text { Animation } \\
\text { dan suara }\end{array}$ & $\begin{array}{ll}\text { - } & \text { Lambatkan suara music } \\
\text { - } & \text { Suara penjelasan kurang besar } \\
\end{array}$ \\
\hline
\end{tabular}

http://journal.unugiri.ac.id/index.php?journal=JaMES 
Pada Tabel 4. dapat dilihat bahwa perbaikan pada aspek pewarnaan. Hasil dari perbaikan menurut saran dari ahli media disajikan dalam gambar sebagai berikut:

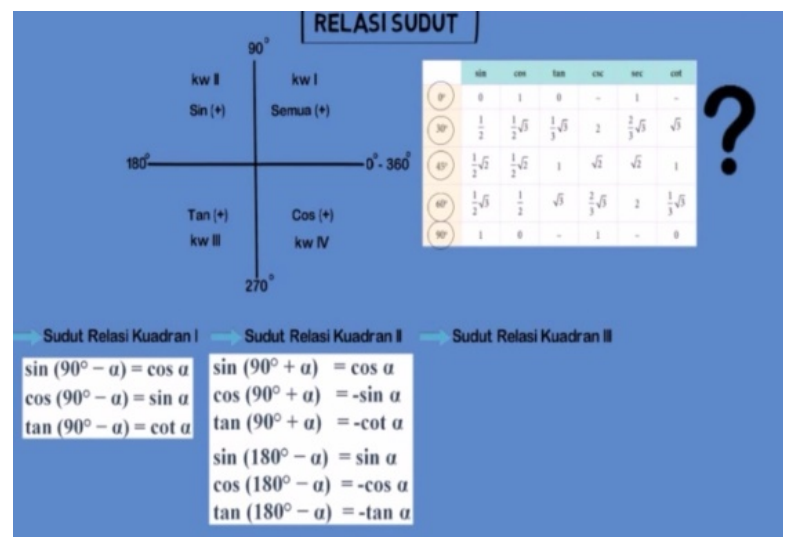

(a) Sebelum revisi

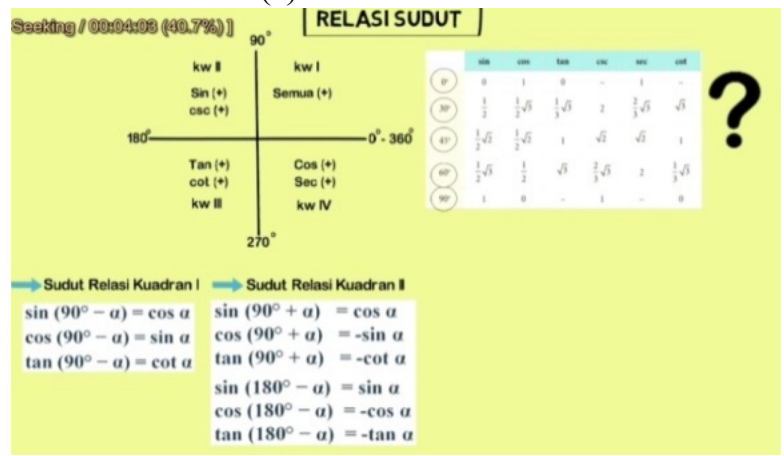

(b) Setelah revisi

Gambar 7. Perbaikan dalam pewarnaan

Ahli media menyarankan untuk menambahkan penyajian dalam aspek penyajian. Hasil dari perbaikan menurut komentar atau saran dari ahli media disajikan dalam gambar berikut:

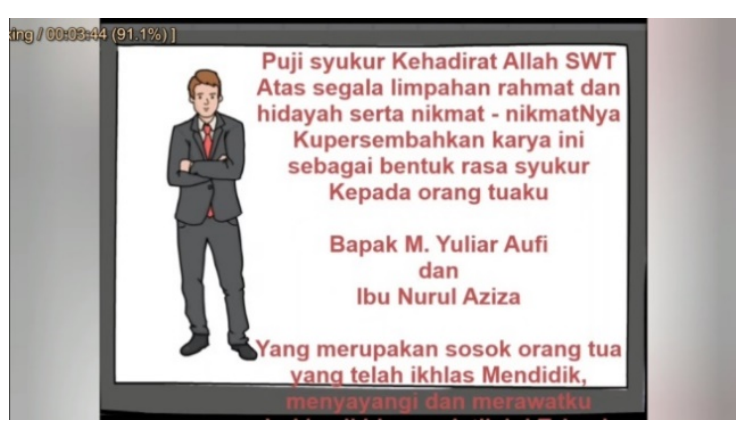

Gambar 8. Penambahan persembahan

\section{Implementation (Tahap Implementasi)}

Pada Tahap Implementasi, dilakukan beberapa kegiatan yaitu uji coba kelayakan atau kemenarikan produk dan kefektifan produk dengan memberikan angket respon peserta didik dan tes hasil belajar dengan melakukan pretest dan posstest pada peserta didik SMA N 1 Bandar Lampung.

\section{a. Uji Kemenarikan}

Setelah produk melalui tahap validasi oleh para ahli serta telah diperbaiki, selanjutnya produk diuji cobakan kepada peserta didik SMA N 1 Bandar Lampung. dengan uji coba yang terdiri dari 10 peserta didik untuk uji kelas kecil dan 31 Peserta didik untuk uji kelas besar uji coba keenarikan ini dilakukan uji coba dalam dua kelas yaitu kelas mipa 4 dan mipa 5 .

Uji coba ini bertujuan untuk menguji kemenarikan dari produk video pembelajaran yang dikembangkan. Akhir uji coba peserta didik diberikan berupa angket kemenarikan dari pembelajaran pembelajaran.

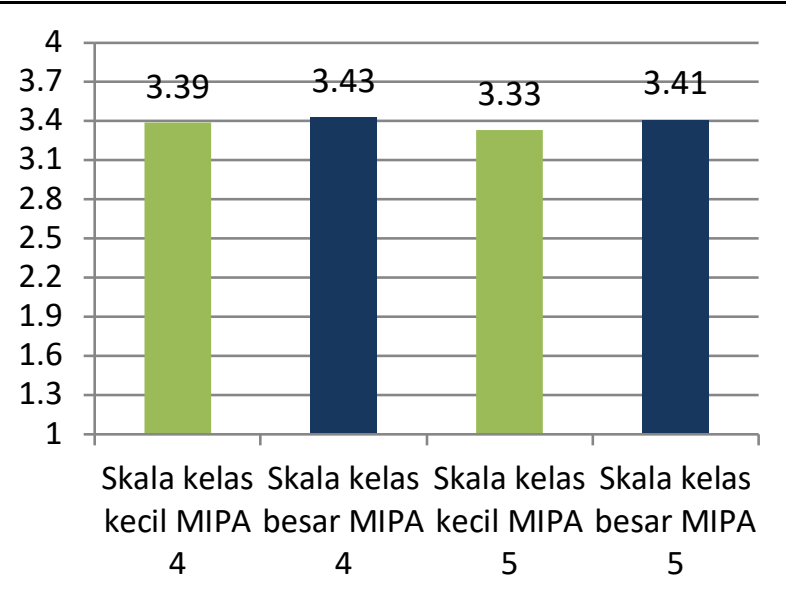

Gambar 9. Grafik Perbandingan Hasil Uji Coba Skala Kecil dan Skala Besar

\section{b. Pembahasan Uji Efektivitas}

Setelah dilakukan uji kemenarikan, peserta didik diberikan tes berupa pretest dan posttest terhadap satu kelas XI SMA N 1 Bandar Lampung menggunakan rumus effect size. Hasil perhitungan dapat dilihat pada tabel 5 .

Tabel 5. Data hasil Perhitungan Pretest dan Posttest

\begin{tabular}{cccccc}
\hline & N & $\begin{array}{c}\text { Skor } \\
\text { Maksi } \\
\text { mum }\end{array}$ & $\begin{array}{c}\text { Skor } \\
\text { Mini } \\
\text { mum }\end{array}$ & $\begin{array}{c}\text { Rata- } \\
\text { Rata }\end{array}$ & $\begin{array}{c}\text { Standar } \\
\text { Deviasi }\end{array}$ \\
\hline Pretest & 31 & 60 & 20 & 42,58 & 43,28 \\
\hline Posttest & 31 & 100 & 60 & 76,12 & 75,42 \\
\hline
\end{tabular}


Berdasarkan data diperoleh hasil perhitungan menggunakan effect Size 0,54 dengan Kriteria sedang, maka dapat disimpulkan ada peningkatan hasil belajar yang signifikan. Hal ini menunjukkan bahwa produk pengembangan Media pembelajaran berbantuan Sparkol Video Scribe efektif dan dapat digunakan dalam proses pembelajaran.

\section{Evaluation (Tahap Evaluasi)}

Tahap terakhir dari model pengembangan ADDIE adalah tahap evaluasi. Evaluasi dilakukan oleh penulis dengan menganalisis data hasil penelitian yang diperoleh yaitu analisis kevalidan media dan materi dari ahli dan angket respon peserta didik. Karena tahap evaluasi telah dilakukan disetiap tahap dan hasil akhir menunjukkan bahwa media pembelajaran video ini mempunyai kriteria sangat menarik digunakan untuk proses pembelajaran.

\section{Penutup}

Penelitian dan pengembangan pada Video pembelajaran menggunakan sparkol viedoscibe ini memperoleh kesimpulan sebagai berikut. Penelitian dan pengembangan ini menghasilkan sebuah produk yakni video pembelajaran yang mengacu pada rancangan penelitian dan pengembangan yang dimodifikasi dari model pengembangan ADDIE. Materi yang dibahas pada media ini adalah Trigonometri. Berdasarkan hasil angket validasi dan respon peserta didik mengenai kelayakan dan kemenarikan Video pembelajaran diperolah rata-rata 3,6 oleh ahli materi, dan 4 oleh ahli media sedangkan hasil angket respon mahasiswa skala kecil diperoleh rata-rata 3,39 dan pada skala besar diperoleh rata-rata 3,43 dengan kriteria sangat menarik. Berdasarkan hasil uji effect size diperolah $\mathrm{E}_{\mathrm{s}}=$ 0,54 dari hasil effect size tersebut kita dapat melihat bahwa media yang sudah disimpulkan layak dapat juga digunakan pada saat proses pembelajaran dengan efektif.

Berdasarkan penelitian yang dilakukan, penulis memiliki beberapa saran yaitu

1. Video pembelajaran berbantuan Sparkol Videoscribe pada materi Trigonometri di 114
SMAN 1 Bandar Lampung ini perlu disempurnakan kembali. Seperti pada penjelasan materi, keselarasan dubbing suara dengan materi yang berjalan pada video pembelajaran, Permasalahanpermasalahan yang menyangkut dalam dikehidupan nyata yang dapat membuat peserta didik akan lebih tertarik dalam proses pembelajaran secara mandiri dan video pembelajaran tersebut dapat bermanfaat dan menghasilkan produk yang lebih berkualitas.

2. Perlu dikembangkan video pembelajaran berbantuan Sparkol Videoscribe pada materi yang lain yang disesuaikan dengan kebutuhan peserta didik serta kondisi sekolah masing-masing agar kegiatan pembelajaran dapat berlangsung efektif dan menyenangkan.

3. Video pembelajaran berbantuan Sparkol Videoscribe pada materi trigonometri ini dapat digunakan dalam proses pembelajaran dengan melihat pengaruh dari hasil proses pembelajaran ataupun dapat menggunkan pendekatan agar proses pembelajaran bisa berjalan dengan baik sehingga hasil belajar peserta didik lebih memuaskan.

\section{Referensi}

[1] Arsyad, A. Media Pembelajaran Jakarta: PT Raja Grafindo Persada, (2013).

[2] Erpina, M. A. Hasjimy, dan A. Salimi, Pengaruh Kooperatif Teknik Talking Stick Terhadap Hasil Pembelajaran Pendidikan Kewarganegaraan di SD, Jurnal Pendidikan Dan Pembelajaran, vol. 3 no. 9, (2014) p.13.

[3] Farida, Mengembangkan Kemampuan Pemahaman Konsep Peserta Didik Melalui Pembelajaran Berbasis VCD. Al-Jabar: Jurnal Pendidikan Matematika, vol. 6 no. 1: (2015) 25-32.

[4] Sari, A. W. "Pengembangan Media Pembelajaran Berbantuan Web Dengan Pendekatan Etnomatematika Pada Pokok Bahasan Bangun Ruang Sisi Datar", Phd Thesis, Uin Raden Intan Lampung, (2017).

http://journal.unugiri.ac.id/index.php?journal=JaMES 
[5] Setyono, Y. Adi, S. Karmin, dan D. Wahyuningsih. Pengembangan Media Pembelajaran Fisika Berupa Buletin Dalam Bentuk Buku Saku Untuk Pembelajaran Fisikakelas Viii Materi Gaya Ditinjau Dari Minat Baca Siswa. Jurnal Pendidikan Fisika, vol.1 no.1, (2013).

[6] Sunarni, S. Pengembangan Media Pembelajaran Power Point Berbasis Sparkol Pada Pokok Bahasan Perumusan Dasar Negara Pada Mata Pelajaran Pkn. Jurnal Penelitian Dan Pendidikan Ips, vol.10 no.3, (2016).
[7] Widyawati, Santi, R. Masykur, dan F. G. Putra, Pengaruh Pembelajaran Picture And Picture (Pap) Terhadap Hasil Belajar Matematika Ditinjau Dari Kecerdasan Spasial, Beta: Jurnal Tadris Matematika, vol.11 no.1, (2018). 